\title{
Low birthweight, preterm, and small for gestational age babies in Scotland, 1981-1984
}

\author{
Silvia de Sanjose, Eve Roman
}

\begin{abstract}
Study objective-The aim was to examine the effect of maternal age, gravidity, marital status, previous perinatal deaths, and parental social class on babies born low birthweight, preterm, and small for gestational age.

Design-The study used data on discharge summaries from all maternity hospitals in Scotland.
\end{abstract}

Setting-The study was based on all singleton deliveries in Scotland.

Participants-The analysis involved information on 259462 singleton babies born during the four years 1981-84 in Scotland.

Measurements and main resultsPrevious perinatal death was found to be the strongest predictor for both preterm and low birthweight. Single mothers were at particularly high risk of having a small for gestational age baby and those who were previously married of having a preterm baby. Women aged less than 20 years old, those over 34 years old, nulligravidae, and those of parity 3 or more were also at increased risk of adverse pregnancy outcome. Mothers and fathers in manual social classes and those who could not be assigned a social class on the basis of their occupation were at increased risk for all three adverse outcomes studied. The babies of parents who were in manual occupations were twice as likely as those of parents in non-manual occupations to be small for gestational age and almost twice as likely to be low birthweight.

Conclusions-Mother's social class is a risk factor for adverse pregnancy outcome independent of maternal age, parity, and adverse reproductive history, and also independent of father's social class. Information on both parents' occupations should be collected in maternity discharge systems.

for Research on

Albert, 150 Cours

69372, Cedex 08,

France

$S$ de Sanjose

Cancer Epidemiology

Unit, Imperial Cancer

Research Fund,

Gibson Building,

Radcliffe Infirmary,

Oxford, United

Kingdom

E Roman

Correspondence to:

Dr Sanjose

Accepted for publication October 1990
Low birthweight, preterm, and small for gestational age are three terms commonly used to describe poor fetal growth and immaturity in the newborn. Low birthweight is usually applied to babies weighing less than $2500 \mathrm{~g}$ and preterm to babies born before 37 weeks gestation. In industrialised countries about $5-7 \%$ of liveborn babies are of low birthweight and $4-9 \%$ are preterm. ${ }^{1-4}$ Unlike low birthweight and preterm delivery there is no generally accepted definition of small for gestational age (SGA), and its estimated prevalence depends on the gestation specific cut off point of the birthweight distribution chosen.

Low birthweight, preterm delivery, and smallness for gestational age have all been associated with a wide range of parental characteristics. ${ }^{5-7}$ These relations are of particular interest for the public health sector, since they define groups within the population for which preventive interventions may be possible.

In this paper we examine the effects of maternal age, gravidity, marital status, previous perinatal death, and parental social class on babies born in Scotland over the four year period 1981-84.

\section{Methods}

Data on 259462 babies born alive in Scotland during the four years 1981-84 were provided by the Scottish Health Service Common Services Agency. In Scotland, information about the parents and about the delivery is recorded on specially designed forms. These discharge summaries (SMR2s) are completed for approximately $99 \%$ of births. The obstetric items recorded include birthweight, gestational age, and baby's sex. Information about mother's age, marital status, gravidity, previous reproductive history, occupation, and partner's occupation is also requested. Social class is assigned on the basis of occupation, using the England and Wales Registrar General's standard classification. ${ }^{8}$

In this paper, low birthweight refers to babies with birthweight below $2500 \mathrm{~g}$ and preterm to babies born before 37 weeks gestation, as measured from the first day of the last menstrual period. Small for gestational age (SGA) babies are defined as those babies falling on or below the 5 th percentile of the appropriate gestation specific birthweight distribution.

The SPSSx and GLIM statistical packages were used for data processing and analyses. ${ }^{9-10}$ Unconditional logistic regression was used to study low birthweight, preterm delivery, and smallness for gestational age. Different models were constructed to estimate the relative risk of each outcome according to different risk factors. The likelihood ratio test, which examines differences in log likelihood statistics, was used to evaluate the fit between models. Interaction effects were also examined and are reported here when statistically significant. ${ }^{11}$

Multiple births $(n=3997)$, babies with weights lower than $500 \mathrm{~g}\left(\mathrm{n}=375,0 \cdot 2^{\circ}{ }_{\mathrm{o}}\right)$, and babies whose SMR2 records had missing data on any of the variables under study $\left(n=2943,1.3^{\circ}{ }_{0}\right)$ were excluded from the analyses. Thus, the final sample consisted of $252147\left(97 \cdot 2^{\circ}{ }_{0}\right)$ of all singleton livebirths. 
Table I Low birthweight ( $L B W)$ preterm, and small for gestational age ( $S G A)$ by parental characteristics. Scotland, 1981-84.

\section{Results}

Of all livebirths, $5.5 \%$ were of low birthweight, $5 \cdot 1 \%$ were preterm, and $5 \%$ were, by definition, small for gestational age. The overall percentage of babies affected by at least one of these adverse outcomes was $9 \cdot 2 \%$.

The characteristics of mothers giving birth to low birthweight, preterm, and SGA babies are summarised in table I. In all cases the $\chi^{2}$ heterogeneity test, which was performed for each

\begin{tabular}{|c|c|c|c|c|}
\hline & $\begin{array}{l}\text { Births } \\
(n)\end{array}$ & $\begin{array}{l}L B W \\
(\%)\end{array}$ & $\begin{array}{l}\text { Preterm } \\
(\%)\end{array}$ & $\begin{array}{l}S G A \\
(\%)\end{array}$ \\
\hline $\begin{array}{l}\text { Mother's age (ye } \\
<20 \\
20-29 \\
30-34 \\
34+\end{array}$ & $\begin{aligned} &s) \\
& 25127 \\
& 168658 \\
& 43386 \\
& 14976\end{aligned}$ & $\begin{array}{l}7 \cdot 7 \\
5 \cdot 2 \\
4 \cdot 9 \\
6 \cdot 1\end{array}$ & $\begin{array}{l}8 \cdot 0 \\
4 \cdot 7 \\
4 \cdot 6 \\
5 \cdot 9\end{array}$ & $\begin{array}{l}5 \cdot 8 \\
5 \cdot 1 \\
4 \cdot 2 \\
4 \cdot 9\end{array}$ \\
\hline $\begin{array}{l}\text { Gravidity } \\
0 \\
1 \\
2 \\
3+\end{array}$ & $\begin{array}{r}108944 \\
87483 \\
37705 \\
18015\end{array}$ & $\begin{array}{l}6 \cdot 3 \\
4 \cdot 6 \\
4 \cdot 6 \\
6 \cdot 3\end{array}$ & $\begin{array}{l}5 \cdot 6 \\
4 \cdot 3 \\
4 \cdot 5 \\
6 \cdot 4\end{array}$ & $\begin{array}{l}6 \cdot 0 \\
4 \cdot 3 \\
4 \cdot 1 \\
4 \cdot 8\end{array}$ \\
\hline $\begin{array}{l}\text { Previous perinat } \\
0 \\
1 \\
2+\end{array}$ & $\begin{array}{r}\text { death } \\
245270 \\
5688 \\
406\end{array}$ & $\begin{array}{r}5 \cdot 3 \\
10 \cdot 0 \\
15 \cdot 4\end{array}$ & $\begin{array}{r}5.0 \\
9.9 \\
17.5\end{array}$ & $\begin{array}{l}5.0 \\
6 \cdot 0 \\
6 \cdot 4\end{array}$ \\
\hline $\begin{array}{l}\text { Marital status } \\
\text { Married } \\
\text { Single } \\
\text { Previously } \\
\text { married }\end{array}$ & $\begin{array}{r}218924 \\
23379 \\
\\
9844\end{array}$ & $\begin{array}{l}5 \cdot 0 \\
8 \cdot 7 \\
8 \cdot 1\end{array}$ & $\begin{array}{l}4 \cdot 7 \\
8 \cdot 6\end{array}$ & $\begin{array}{l}4 \cdot 7 \\
7 \cdot 2 \\
7 \cdot 0\end{array}$ \\
\hline $\begin{array}{l}\text { Mother's social } \\
\text { Non-manual } \\
\text { Manual } \\
\text { Other } \\
\text { Housewives }\end{array}$ & $\begin{aligned} & \text { Iss } \\
& 71478 \\
& 32784 \\
& 23015 \\
& 124870\end{aligned}$ & $\begin{array}{l}4 \cdot 8 \\
6 \cdot 6 \\
7 \cdot 9 \\
5 \cdot 2\end{array}$ & $\begin{array}{l}4.6 \\
5 \cdot 6 \\
7.9 \\
4.9\end{array}$ & $\begin{array}{l}4 \cdot 6 \\
6 \cdot 3 \\
6 \cdot 6 \\
4 \cdot 7\end{array}$ \\
\hline $\begin{array}{l}\text { Father's social cl } \\
\text { Non-manual } \\
\text { Manual } \\
\text { Other }^{2}\end{array}$ & $\begin{array}{r}67940 \\
109806 \\
74401\end{array}$ & $\begin{array}{l}3 \cdot 8 \\
5 \cdot 3 \\
7 \cdot 2\end{array}$ & $\begin{array}{l}3.4 \\
4.4 \\
5.8\end{array}$ & $\begin{array}{l}3 \cdot 4 \\
5 \cdot 1 \\
6 \cdot 1\end{array}$ \\
\hline All & 252147 & 5.5 & $5 \cdot 1$ & 5.0 \\
\hline
\end{tabular}

Table II Adjusted relative risks (RR) with $95 \%$ confidence intervals (CI) for low birthweight ( $L B W$ ), preterm, and small for gestational age ( $S G A$ ) by mother's age, gravidity, previous perinatal death, marital status, and parental social class, Scotland, $1981-84$

\begin{tabular}{|c|c|c|c|}
\hline & $\begin{array}{l}L B W \\
R R(95 \% C I)\end{array}$ & $\begin{array}{l}\text { Preterm } \\
R R(95 \% C I)\end{array}$ & $\begin{array}{l}S G A \\
R R(95 \% C I)\end{array}$ \\
\hline $\begin{array}{l}\text { Mother's age (years) } \\
<20 \\
20-29 \\
30-34 \\
>34\end{array}$ & $\begin{array}{l}1 \cdot 2(1 \cdot 1,1 \cdot 2)^{\star} \\
1 \cdot 0 \\
1 \cdot 1(1 \cdot 0,1 \cdot 1)^{\star} \\
1 \cdot 2(1 \cdot 1,1 \cdot 4)^{\star}\end{array}$ & $\begin{array}{l}1.4(1 \cdot 3,1 \cdot 5)^{\star} \\
1 \cdot 0 \\
1 \cdot 0(0 \cdot 9,1 \cdot 0) \\
1 \cdot 2(1 \cdot 1,1 \cdot 3)^{\star}\end{array}$ & $\begin{array}{l}0.9(0.8,0.9)^{\star} \\
1.0 \\
0.9(0.9,1 \cdot 0) \\
1.1(1 \cdot 0,1 \cdot 1)^{\star}\end{array}$ \\
\hline $\begin{array}{c}\text { Gravidity } \\
0 \\
1 \\
2 \\
3+\end{array}$ & $\begin{array}{l}1 \cdot 3(1 \cdot 2,1 \cdot 3)^{\star} \\
1 \cdot 0 \\
1 \cdot 1(1 \cdot 0,1 \cdot 1)^{\star} \\
1 \cdot 3(1 \cdot 2,1 \cdot 3)^{\star}\end{array}$ & $\begin{array}{l}1 \cdot 1(1 \cdot 1,1 \cdot 2)^{\star} \\
1 \cdot 0 \\
1 \cdot 1(1 \cdot 1,1 \cdot 3)^{\star} \\
1 \cdot 4(1 \cdot 3,1 \cdot 5)^{\star}\end{array}$ & $\begin{array}{l}1.4(1 \cdot 3,1 \cdot 4)^{\star} \\
1.0 \\
0.9(0.9,1.2) \\
1 \cdot 1(1 \cdot 0,1 \cdot 2)^{\star}\end{array}$ \\
\hline $\begin{array}{l}\text { Previous perinatal death } \\
\text { None } \\
1 \text { or more }\end{array}$ & $\begin{array}{l}1 \cdot 0 \\
2 \cdot 1(1 \cdot 9,2 \cdot 4)^{\star}\end{array}$ & $\begin{array}{l}1 \cdot 0 \\
2 \cdot 3(2 \cdot 1,2 \cdot 5)^{\star}\end{array}$ & 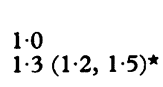 \\
\hline $\begin{array}{l}\text { Marital status } \\
\text { Married } \\
\text { Single } \\
\text { Previously } \\
\text { married }\end{array}$ & $\begin{array}{l}1 \cdot 0 \\
1 \cdot 3(1 \cdot 2,1 \cdot 4)^{\star} \\
1 \cdot 5(1 \cdot 3,1 \cdot 6)^{\star}\end{array}$ & $\begin{array}{l}1.0 \\
1.4(1.3,1.5)^{\star}\end{array}$ & $\begin{array}{l}1.0 \\
1.7 \\
(1.5,1.8)^{\star}\end{array}$ \\
\hline $\begin{array}{l}\text { Mother's social group } \\
\text { Non-manual } \\
\text { Manual } \\
\text { Housewives } \\
\text { Other }^{\mathrm{a}}\end{array}$ & $\begin{array}{l}1 \cdot 0 \\
1 \cdot 2(1 \cdot 2,1 \cdot 3) \\
1 \cdot 1(1 \cdot 1,1 \cdot 2) \\
1 \cdot 3(1 \cdot 2,1 \cdot 4)\end{array}$ & $\begin{array}{l}1 \cdot 0 \\
1 \cdot 1(1 \cdot 1,1 \cdot 3) \\
1 \cdot 1(1 \cdot 1,1 \cdot 1) \\
1 \cdot 3(1 \cdot 1,1 \cdot 3)\end{array}$ & $\begin{array}{l}1 \cdot 0 \\
1 \cdot 3(1 \cdot 2,1 \cdot 4) \\
1 \cdot 2(1 \cdot 1,1 \cdot 2) \\
1 \cdot 3(1 \cdot 2,1 \cdot 4)\end{array}$ \\
\hline $\begin{array}{l}\text { Father's social group } \\
\text { Non-manual } \\
\text { Manual } \\
\text { Other }^{\mathrm{a}}\end{array}$ & $\begin{array}{l}1.0 \\
1 \cdot 5(1 \cdot 4,1 \cdot 5) \\
1 \cdot 7(1.6,1 \cdot 8)\end{array}$ & $\begin{array}{l}1 \cdot 0 \\
1 \cdot 2(1 \cdot 2,1 \cdot 3) \\
1 \cdot 4(1 \cdot 3,1 \cdot 5)\end{array}$ & $\begin{array}{l}1.0 \\
1.5(1.4,1.5) \\
1.6(1.4,1.7)\end{array}$ \\
\hline
\end{tabular}

Relative risks adjusted for all the other factors in the table and baby's sex Other includes: inadequately described occupations, armed forces, students, and occupation not stated.

$\star \mathrm{p}<0.05$ of the variables and for each outcome, was statistically significant $(p<0.05)$. Each of the three outcomes appears to have a $U$ shaped relationship with maternal age, the percentages being highest in those under 20 years and those over 34 years of age. This relationship was more marked for low birth weight and preterm delivery than for SGA. The association between the three outcomes and gravidity is similarly $U$ shaped. Again the relationship appears weakest for SGA. Mothers reporting one or more prior perinatal death were more than twice as likely as mothers reporting no prior deaths to have a low birthweight or preterm baby. By comparison, the relationship between previous perinatal death and SGA is less marked. Married mothers had considerably fewer low birthweight, preterm, and SGA babies than single or previously married mothers.

When mother's occupation was used to assign social class, the lowest percentage of all three outcomes was recorded in the "non-manual" category and the highest in the "other" category (table I), with manual workers falling in between. The relationship was similar when father's occupation was used as the basis for social class classification. For both non-manual and manual workers, however, the proportion of babies with an adverse outcome was greater when mothers', rather than fathers', occupation was used.

Table II gives the relative risks of adverse outcome adjusted for the effects of all variables in table I and for baby's sex. For each adverse outcome the group at lowest risk of low birthweight was taken as the reference category. After adjustment the relationships remained broadly similar to those already described for the crude analysis. Closer inspection of the data showed, however, that the association between low birthweight and gravidity varied with age (fig 1).

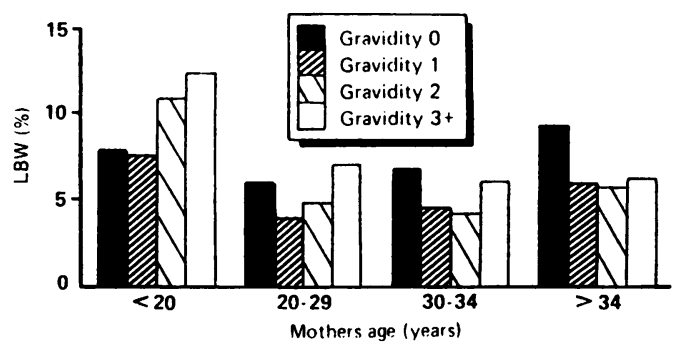

Figure 1 Low birthweight by maternal age and gravidity

In young mothers (less than 20 years old), low birthweight increased with increasing gravidity, the risk for mothers of gravidity 3 or more being approximately two and a half times greater than of that of mothers in their first pregnancy. In older mothers (more than 34 years old) the relationship was reversed, women having their first baby having twice the risk of those having a second or higher order birth.

The adjusted relative risks for low birthweight, preterm delivery, and smallness for gestational age for mothers and fathers by social class are graphed in figs 2 and 3 . Social class $I$ is the reference category. When women's occupation is used as the basis for social class classification the relative risk for low birthweight, preterm delivery, and SGA increases from social class I 


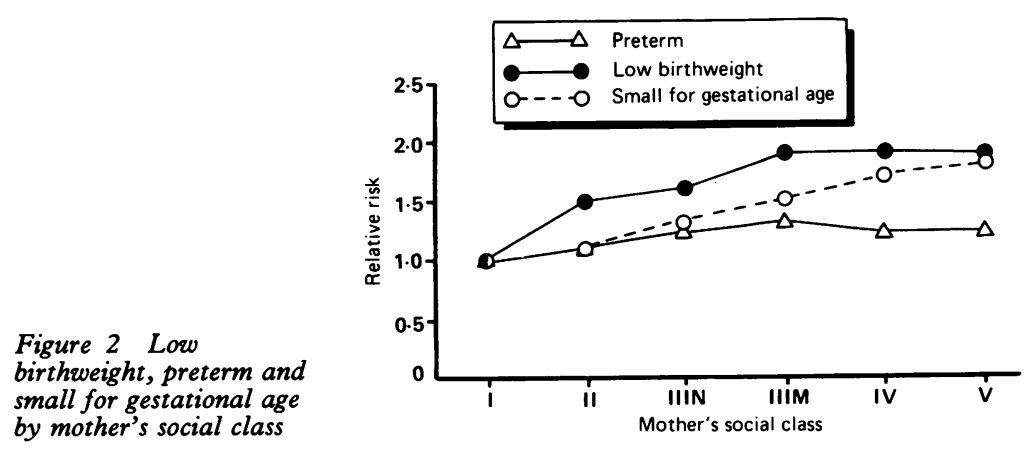

Figure 3 Low birthweight, preterm, and small for gestational age by father's social class

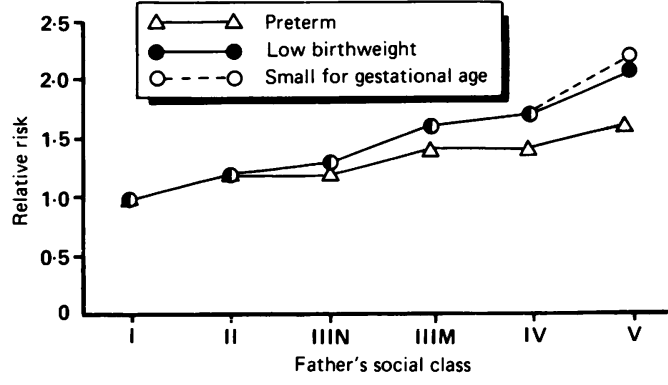

through to social class IIIM: the gradient being greatest for low birthweight, followed by SGA, and then preterm delivery. For low birthweight and preterm delivery no further increase with social class occurs, whereas for SGA the adjusted relative risk continues to increase from 1.5 in social class IIIM to 1.8 in social class V. When father's occupation is used as the basis for social class classification there is a consistent positive gradient from social class I through to social class $\mathrm{V}$ for all three adverse outcomes (fig 3).

The social class gradients become more marked when the joint effects of mothers' and fathers' social class are considered (table III). The risk of having a low birthweight baby, for example, when the mother is a manual worker increases from $1 \cdot 2$ when the father has a non-manual job to 1.8 when the father has a manual job, and further to 1.9 when the father is classified as "Other".

\section{Discussion}

The data analysed in this paper come from a single source. At present, no similar collection system

Table III Foint effects of parental occupation on low birthweight, preterm delivery, and smallness for gestational age, Scotland 1981-1984. Relative risks (RR) and 95\% confidence intervals $(\mathrm{CI})$.

\begin{tabular}{|c|c|c|c|c|}
\hline & \multicolumn{4}{|l|}{ Mothers } \\
\hline & Non-manual & Manual & Other ${ }^{a}$ & Housewives \\
\hline & $\overline{R R(95 \% C I)}$ & $\overline{R R}(95 \% C I)$ & $R R(95 \% C I)$ & $R R(95 \% C I)$ \\
\hline \multirow[b]{2}{*}{$\begin{array}{l}\text { Fathers: } \\
\text { Non-manual } \\
\text { Manual } \\
\text { Other }^{2}\end{array}$} & \multicolumn{4}{|c|}{ Low birthweight } \\
\hline & $\begin{array}{l}1.0 \\
1.4(1.3,1.5) \\
1.6(1.5,1.7)\end{array}$ & $\begin{array}{l}1.2(1 \cdot 2,1 \cdot 3) \\
1.8(1 \cdot 6,1 \cdot 9) \\
1.9(1.8,2 \cdot 1)\end{array}$ & $\begin{array}{l}1 \cdot 3(1 \cdot 2,1 \cdot 4) \\
1 \cdot 8(1 \cdot 7,2 \cdot 0) \\
2 \cdot 0(1 \cdot 8,2 \cdot 2)\end{array}$ & $\begin{array}{l}1.1(1.1,1.2) \\
1.6(1.5,1.7) \\
1.8(1.7,1.9)\end{array}$ \\
\hline \multirow[b]{2}{*}{$\begin{array}{l}\text { Fathers: } \\
\text { Non-manual } \\
\text { Manual } \\
\text { Other }\end{array}$} & \multicolumn{4}{|c|}{ Preterm } \\
\hline & $\begin{array}{l}1 \cdot 0 \\
1.2(1 \cdot 2,1 \cdot 3) \\
1.4(1.3,1.5)\end{array}$ & $\begin{array}{l}1 \cdot 1(1 \cdot 1,1 \cdot 3) \\
1.3(1.3,1.4) \\
1.5(1.4,1.7)\end{array}$ & $\begin{array}{l}1.2(1 \cdot 1,1 \cdot 3) \\
1.4(1.3,1.5) \\
1.6(1.5,1.7)\end{array}$ & $\begin{array}{l}1 \cdot 1(1 \cdot 0,1 \cdot 1) \\
1 \cdot 3(1 \cdot 2,1 \cdot 4) \\
1 \cdot 5(1 \cdot 4,1 \cdot 6)\end{array}$ \\
\hline Fathers: & \multicolumn{4}{|c|}{ Small for gestational age } \\
\hline $\begin{array}{l}\text { Non-manual } \\
\text { Manual } \\
\text { Other }\end{array}$ & $\begin{array}{l}1.0 \\
1.5(1.4,1.6) \\
1.6(1.4,1.7)\end{array}$ & $\begin{array}{l}1 \cdot 3(1 \cdot 2,1 \cdot 4) \\
2 \cdot 0(1 \cdot 9,2 \cdot 1) \\
2 \cdot 1(2 \cdot 0,2 \cdot 3)\end{array}$ & $\begin{array}{l}1 \cdot 3(1 \cdot 2,1 \cdot 4) \\
1.9(1 \cdot 8,2 \cdot 1) \\
1.9(1 \cdot 7,2 \cdot 2)\end{array}$ & $\begin{array}{l}1.2(1 \cdot 1,1 \cdot 2) \\
1.7(1 \cdot 6,1 \cdot 9) \\
1.9(1.7,2 \cdot 0)\end{array}$ \\
\hline
\end{tabular}

exists in England and Wales. In these Scottish data, low birthweight, preterm and small for gestational age were associated with previous perinatal death, marital status, maternal age, parity, and social class. These findings are consistent with previous reports. ${ }^{12-14}$ Previous perinatal death was found to be the strongest predictor of adverse pregnancy outcome and this effect was more marked for low birthweight and preterm delivery than for SGA (table II). Marital status clearly predicted different levels of adverse pregnancy outcome. Single and formerly married mothers (ie, separated, divorced, and widowed) were, on average, at higher risk than married mothers. Marital status has been shown to be associated with a number of behavioural patterns and habits which could be related to perinatal outcome. As compared to married women, for example, those who are single are less likely to use health services, and those who are previously married are more likely to smoke. ${ }^{15} 16$

Mothers younger than 20 years and those older than 34 years had higher risks for low birthweight and preterm delivery than mothers within the 20 to 34 year age range. Overall, the relationship between gravidity and low birthweight and preterm delivery was similarly $U$ shaped. However, in young mothers the risk of low birthweight increased with increasing gravidity. This relationship was not found for preterm delivery and SGA. Mothers who by the age of 20 years have already had three pregnancies must have had short pregnancy intervals, and short birth spacing has been associated with an increased risk of low birthweight. ${ }^{17}$ Moreover, mothers with high rank gravidity and short birth spacing were more likely to be included more than once in the study, since each mother appears in the analyses as many times as she had births. This could bias some of the associations if parents in a certain category were more likely to have more adverse pregnancy outcomes unrelated to the factors under study. ${ }^{18}$

Traditionally the relationship between social class and pregnancy outcome has concentrated on the social class of married women as measured by their husbands' occupation. In the data examined here social status of either parent was found to be related to the risk of adverse outcome (tables I and II). When the joint effects of mothers' and fathers' social class were examined, smallness for gestational age was most affected by differences in parental social class, while preterm delivery was the least affected (table III). Babies whose parents were both manual workers were twice as likely as those whose parents were both non-manual workers to be small for gestational age. Clearly, mothers' social class has an effect independent of fathers' social class; and information on both parents' occupations should be collected in maternity discharge systems. 1 Macfarlane A, Mugford M. Birth counts: statistics of pregnancy and childbirth. 1st ed. London: HMS
Office of Population Censuses and Surveys. Monitor D113 88/1.

3 Villar J, Belizan JM. The relative contribution of prematurity and fetal growth retardation to low birthweight in developing and developed societies. Am $\mathcal{F}$ Obstet Gynecol 1982; 143: 793-8.

4 Institute of Medicine. Preventing low birthweight. 1st ed. Washington: National Academy Press, 1985. 
5 Stein A, Campbell EA, Day A, McPherson K, Cooper PJ. Social adversity, low birthweight and preterm delivery. BMF 1987; 295: 291-3.

6 Chamberlain R, Chamberlain G, Howlett B, Claireaux A. British births 1970. 1st ed. London: W. Heinemann Medical Books, 1975.

7 Cnattingius S, Axelsson O, Hammarlund K. Perinatal outcome for small for gestational age infants from the
unselected, area-based population. Early Hum Dev 1987; 15: 95-101.

8 Office of Population Censuses and Surveys. Simplified 1980 occupation classification. London: HMSO, 1985.

9 SPSSx user's guide. 2nd ed. Chicago: SPSS 1986. Baker RJ, Nelder JA. The GLIM system
Numerical Algorithms Group, 1978.

1 Breslow NE, Day NE. Statistical methods in cancer research. IARC Scientific Publication No 32, 1st ed. Lyon: IARC, 1980 .
12 Strachan DP. Antenatal booking and perinatal mortality in Scotland 1972-1982. Int F Epidemiol 1987; 16: 229-33.

13 Mitchell RG. Objectives and outcome of perinatal care. Lancet 1985; ii: 931-3.

14 Pickering RM. Relative risks of low birthweight in Scotland . Soc Sci Med 1980; 14A, 633-43.

16 Murphy M, Dawson J, Fitzpatrick R. Marital status and women who smoke. Lancet 1989; ii: 1286.

17 World Health Organization Expert Committee on Maternal and Child Health: Public health aspects of low birthweight. Third report of Child Health. Technical Report Series No 217. Geneva: WHO, 1961

18 Skjaerven R, Wilcox AJ, Lie RT, Irgens LM. Selective fertility and the distortion of perinatal mortality. $A m \mathcal{F}$ Epidemiol 1988; 128: 1352-63. 